\title{
"AN ENEMY OF OUR TIMES": GODARD'S AESTHETICS OF CONTEMPORANEITY AS OPPOSITION TO SYNCHRONIZATION
}

\section{A B S T R A C T}

Towards the end of his film essay Histoire(s) du cinéma Jean-Luc Godard calls himself an "enemy of our times", of "the totalitarianism of the present as applied mechanically every day more oppressive on a planetary scale." The article regards Histoire(s) du cinéma (19881998) as "a thinking form" that tries to resist the synchronizing, standardizing time of global capital, the pervasive uniformity of the global super-present, brought about by today's televisual and digital communications, which threatens to trivialise the different processes of memory and history, and art and culture in general. According to philosopher Bernard Stiegler, the final stage of capitalism is the control and synchronization of what former CEO of TF1 Patrick le Lay called "available brain time". The paper argues that Godard's work opposes this control and synchronization of our minds through an aesthetics of contemporaneity. The argument is based on the development of a theoretical framework that combines recent theories of contemporaneity with theories of image-politics. Focusing on the interrelation of the individual, the social and the media environments, the paper deals with Godard's image-political creation of temporal contemporaneity through a montage of clips of old films and newsreels, photographs, stills, images of paintings, new footage, advertisements, music, sound and voice recordings, textual citation, narration and commentary. 
Towards the end of the film essay Histoire(s) du cinéma Jean-Luc Godard calls himself an "enemy of our times", of "the totalitarianism of the present as applied mechanically every day more oppressive on a planetary scale. This faceless tyranny that effaces all faces for the systematic organization of the unified time of the moment. This global, abstract tyranny, which I try to oppose from my fleeting point of view." "The aim of this paper is to argue that Histoire(s) $d u$ cinéma can be seen as "a thinking form" that tries to resist the synchronizing, standardizing time of global capital, the pervasive uniformity of the global super-present, brought about by today's televisual and digital communications, which threatens to trivialise the different processes of memory and history, and art and culture in general - instead of allowing for a contemporaneity of difference. ${ }^{2}$ According to philosopher Bernard Stiegler, the final stage of capitalism is the control and synchronization of what former CEO of the major French TV channel TF1, Patrick le Lay called "available brain time":

"Our era is characterised by synchronization. The programme industries attempt to synchronize the activities of everyone's consciousness; a control over the life of souls through marketing and television, which establishes the psycho-power characteristic of our time. [...] From now on wherever you go, you have the same modes of production and distribution. This globalization comes at the price of a synchronization of modes of life and thought. Today, this becoming is extended to all aspects of our lives and destroys the singularity of existence through consumerism, which liquidates life skills [les savoir-vivre]."

I will try to argue that Godard's work opposes this control and synchronization of our minds through an aesthetics of contemporaneity.

\section{CONTEMPORARY IMAGE-POLITICS}

Therefore what interests me here is also related to the question of the image and our relation to images, which has gained ever more importance since Guy Debord's classic analysis of the 'becoming-image' of capital that gave us the name of the society of the spectacle, where our very communicative nature, our language and images are separated in an autonomous sphere, and in which the entire social production has been falsified. ${ }^{4}$ It seems, however, that our relation to images is even more complex than what it appeared in 1967. The spectacle is not merely separated and external to us, it is part of who we are, part of our consciousness, and it strongly influences the ways in which we experience the world, each other, and ourselves. "We are not," as philosopher Jacques Rancière remarks, " in front of the images; we are in the middle of them, just as they are in the middle of us. The question is to know how to circulate among them, and how to get them to circulate as well." 
Thus, the new forms of image production and image circulation in contemporary media culture, not least on the Internet, bring the issue of circulation, or what filmmaker and theorist Hito Steyerl terms "circulationism" to the fore. Circulationism has not to do with the art of making images, but with the postproduction, launching, and acceleration of images - and with the public relations of images across social networks that both establish and tear apart "communities loosely linked by shared attention deficit". ${ }^{6}$ How is it possible for contemporary artistic practice to critically react to this circulationism, the uniformed time of the global super-present, and its concomitant attention deficit?

\section{CONTEMPORANEITY}

My interest is the quality of this present, the quality of our present, as I would claim that the present present differs from past presents, the contemporary contemporary differs from earlier contemporaries. As among others philosopher Peter Osborne and art historian Terry Smith observe, the idea of contemporaneity as a condition is new, and Osborne stresses that:

"what seems distinctive and important about the changing temporal quality of the historical present over the last few decades is best expressed through the distinctive conceptual grammar of con-temporaneity, a coming together not simply 'in' time, but of times: we do not just live or exist together 'in time' with our contemporaries - as if time itself is indifferent to this existing together - but rather the present is increasingly characterised by a coming together of different but equally 'present' temporalities or 'times', a temporal unity in disjunction, or a disjunctive unity of present times."

Time is not an empty duration unaffected by the events that fill it, and time itself has a history. Time is constructed, multiply, and asymmetrical, neither homogeneous nor blank, and there are many different co-existing ways of being in time and belonging to it. As Osborne observes, the term "contemporaneity" should not be seen as a simple periodizing category, but rather as designator of the changing temporal quality of the historical present. "The contemporary" points to an awareness of what it is to be in the present whilst being attentive to the presence of other kinds of time. It designates a multi-chronicity and a thickening of the present in contemporary experience, an extension of the present beyond the immediate instant back and forward in time and across the globe. "Contemporaneity," Terry Smith claims, "consists precisely in the constant experience of radical disjunctures of perception, mismatching ways of seeing and valuing the same world, in the actual coincidence of asynchronous temporalities, in the jostling contingency of various cultural and 
social multiplicities." interconnectedness of different times is inseparable from image circulation and the role of images in the global spectacle. The world is becoming "uniformed" or "common" not least because of the global circulation of images.

On the background of this general diagnosis of the historical present as being defined by a coming together of different times, which at the same are subjected to synchronization and standardization, I will now finally return to Jean-Luc Godard.

\section{GODARD'S HISTORY WRITING THROUGH MONTAGE}

Histoire(s) du cinéma is a 264-minute video essay on the history or histories of cinema and its relation to the $20^{\text {th }}$ century, which was completed in 1998 (so it is still somewhat contemporary; Godard may be said to have had an intuition of the changes in our current experience of time). It consists of four chapters, each one divided into two parts, making for a total of eight episodes, and originates from an experimental series of improvised talks and lectures Godard gave at the Montreal Film School in the late 70s. Rather than delivering traditional lectures, Godard proposed a form of historical cinematic montage where he showed one of his own films along with clips from a range of other films as a basis for reflections on cinema history and his own place within it. ${ }^{9}$ The opening two long episodes were eventually broadcast on French television in 1988 and 1989, and the subsequent six episodes were screened at festivals and museums in 1997 and 1998. In 1998 the work was released as a complete and re-edited whole on VHS, and in 2008 it became available on DVD. Made for TV and later VHS and DVD the work is meant to be seen in the everyday environment of the viewer; on her TV or computer where she encounters or is bombarded with a dizzying number of images every day - where her brain is made available by the programme industries, according to Stiegler.

The video essay weaves together clips of old films and newsreels, photographs, stills, images of paintings, new footage, advertisements, music, sound and voice recordings, textual citation, narration and commentary, primarily by Godard himself, but also by the actors Juliette Binoche and Julie Delpy, and writers like André Malraux, Ezra Pound and Paul Celan. Every now and then we also see Godard at his desk with his books and his typewriter orchestrating it all. In an experimental form, which breaks with the linear development of narrative cinema in favour of a kind of contemporaneity, as I will argue in the following, the work layers, superimposes, and juxtaposes all the filmic, musical, textual, voice-over, and art historical citations on top of each other, dealing with a number of different subjects ranging from film and politics to globalization, memory, genocide, art and God..$^{10}$ 
Godard's history writing is based on a plural concept of history that also reflects the condition of contemporaneity. The unified big history is unachievable but all the innumerable potential histories contained in it are not. They are all possible histories that do not pretend to be the only possible one, but merely possible. ${ }^{11}$ The parenthetical "s" in the title Histoire(s) du cinéma indicates in itself the contemporaneity of a number of different histories; there is no one history. Furthermore, the title of Chapter 1A, "Toutes les histoires" (All the Stories), not only suggests that history, like public memory, is constituted by multiple histories from a variety of competing perspectives, but also that history must include all perspectives and voices, including the voices of Hitler, Himmler, and a number of other perpetrators. ${ }^{12}$ I therefore understand Rancière to a certain extent when he criticizes Godard for linking heterogeneous elements into a homogeneous layer of mystery, "where all yesterday's conflicts become expressions of intense co-presence," and for "constructing the world of 'images' as a world of general co-belonging and inter-expression." 13 I would argue, however, that this co-presence is not to be deplored, but to be appreciated as a possible actualisation of different temporalities and pasts.

By juxtaposing documentary footage, photographic evidence next to fiction film, popular songs, propaganda, recorded voices and testimony, and by mixing texts, soundtracks, music and double exposures, by not hesitating to mount the historical archive with the artistic repertory of global cinema, the assemblages of Histoire(s) du cinéma invites us to reflect upon how to distinguish 'a just image' (une image juste) from 'just an image' (juste une image) of different pasts, not least of the Holocaust.

One of the most discussed sequences in Histoire(s) du cinéma occurs in the last minutes of chapter 1A, when Godard declares: "and if George Stevens hadn't used the first 16 millimetre colour film at Auschwitz and Ravensbrück, Elizabeth Taylor would never have found a place in the sun." The fragment involves the superimposition within a single frame of Stevens's images of Holocaust victims, a stop-started sequence from Stevens's film A Place in the Sun (1951) with a swimsuit-clad Elizabeth Taylor, and Mary Magdalene from Giotto's Noli me tangere (1304-6). Giotto's painting is tilted ninety degrees so it looks as if Mary Magdalene is descending like an angel to draw Elisabeth Taylor up towards the heavens. Godard's voice accompanies two images from Goya's Disasters of war series of etchings (1810-20) and pauses before the line about Elizabeth Taylor's happiness. During the pause the screen fades to black, and a colour image of bodies of Holocaust victims piled in railway wagons at Dachau appears out of the darkness, while gradually the black and white image of Taylor caressing the head of Montgomery Clift in A Place in the Sun 
is superimposed over the colour image of the Holocaust victims. The head of one of the victims seems to rest on her arm close to her chest along with that of Clift's. The colours bleed into the image of Taylor as Clift's image disappears. Rather than suggesting a replacement of the figure of the victim for Clift or vice versa, this fading in and out offers a brutal contrast to this same image. ${ }^{14}$

In this way Godard uses montage - what he calls "mon beau souci", my beautiful care - as a technique for articulating the past. According to Godard only montage can produce historical connections because history is always a matter of juxtaposing one thing with another. Time-based audio-visual media like film and video thus produce specific modes of historical articulations through techniques of movement decomposition and superimposition of images. ${ }^{15}$ Incorporating both moving and still images Godard creates a complex assemblage of perspectives from different temporal strata. Painting and photography in particular are often perceived as a slice of time, or suspended time, while film, as a time-image, is linked to a temporality that endures, to a time that reproduces the flow of "real time". By basing his video essay on both photographs, paintings and film Godard blurs these apparently opposite time economies for the benefit of a contemporaneity of multiple, heterogeneous temporalities that compete with and overlap each other, suggesting a notion of a fractured, layered, multiple temporality. ${ }^{16}$

\section{THE AESTHETICS OF CONTEMPORANEITY}

As in other works and texts Godard draws upon Walter Benjamin's critique of the historicist conception of time only in the abstract form of an "empty, homogeneous continuum" that the historian only needs to fill with a succession of facts, thereby producing a "history of events". The problem with this abstract notion of time and the historicist notion of history as a linear development is that once time is divided into a chronological series of instants, any moment in the past becomes unreachable as it is irremediably severed from the present by an infinite number of instants. ${ }^{17}$ It becomes a dead object of knowledge, something that can be accumulated without end, but which will never form what Benjamin calls the "true picture of the past". "The true picture of the past flits by," Benjamin writes in his "Theses on the Philosophy of History":

"The past can be seized only as an image which flashes up at the instant when it can be recognized and is never seen again. [...] For every image of the past that is not recognized by the present as one of its own concerns threatens to disappear irretrievably. To articulate the past historically does not mean to recognize it 'the way it really was' (Ranke). It means to seize hold of a memory as it flashes up at a moment of danger." 18 
Godard's artistic practice in Histoire(s) is defined by montage as the bringing together for the first time of elements that are not predisposed to be linked. It creates singular images by connecting well known but previously unconnected elements and images. Godard uses montage as an experimental method for the production of historical intelligibility and to construct what Benjamin called "the image in the now of its recognizability". As Benjamin writes in one of the notes for his Arcades Project:

"Every present day is determined by the images that are synchronic with it: each 'now' is the now of a particular recognizability. In it, truth is charged to the bursting point with time. [...] It is not that what is past casts its light on what is present, or what is present its light on what is past; rather image is that wherein what has been comes together in a flash with the now to form a constellation. In other words: image is dialectics at a standstill. For while the relation of the present to the past is purely temporal, the relation of what-has-been to the now is dialectical: not temporal in nature but figural $<$ bildlich $>$. Only dialectical images are genuinely historical [...]. The image that is read [is] the image in the now of its recognizability." 19

Historical knowledge only comes about through the 'now', that is, through a state of our present experience from which emerges, from amongst the immense archive of texts, images and testimonies of the past, a moment of memory and readability. ${ }^{20}$ This critical moment appears according to Benjamin as an image: a dialectical image in which 'what has been comes together in a flash with the now to form a constellation,' or a coming together of times, a contemporaneity of past and present.

By speaking of the image that is read and recognized Benjamin not only points to the formal aspects of the image but also to the time of its reading and recognition, that is, to the recognizing spectator. This understanding of the image as something that develops out of the spectator's relation with the image is also explicit in Godard's own comments on his artistic practice of montage: "But an image doesn't exist. This is not an image, it's a picture. The image is the relation with me looking at it dreaming up a relation at [sic] someone else. An image is an association." ${ }^{21}$ The spectator so to speak animates the image. The montage and interruptions that allow the true picture of the past to flash up for an instant before it disappears irretrievably is a spacing of time and an opening in which memory can emerge. The image exists only in the plural according to Godard's conception of it. Without reducing their differences or provoking a fusion of them, it appears in the intermediate space between two 
images, which can either be located in the many instances of black screens, or in the intervals of the superimpositions where two images are co-present on the screen (in the difference between them). Godard comments: "The basis is usually two, always to present from the start two images rather than one, that is what I call image, the one made of two." ${ }^{22}$ In this way the montage appears as a spatializing narrative into which the spectator can "enter" - a spatialization of time in which the time-connections are felt. With reference to the recurring sentence "une forme qui pense", "a form that thinks", the montage can thus be regarded as an epistemological and dramaturgical space in which various kinds of temporality may be produced or shown to coexist. ${ }^{23}$

It is thus not only about the time of the images. Godard shows us these images and movie clips. They are addressed to us as viewers, which means that our time, our present, is being involved - our historical present of the year 2015 as well as our "phenomenological present" for the duration of our watching and listening to the film. This adds another dimension to the time structure of the work. The temporality of the viewer, who - to use the vocabulary of reception aesthetics - concretizes the artefact of the video essay and gives it an individual form, take part in the constellation of the dialectical image.

The montage is a production of historical knowledge. It is not, however, in the case of Godard a knowledge production that controls the work of the spectator. The potential readings and recognitions of his complex montage images are almost infinite and the product of their combination cannot be predicted as it only appears in the here and now of each particular vision, that is, in each concretization of the visual artefact, which each time gives it an individual form. Histoire(s) du cinéma demonstrates that memory is something that has to be made, not just received. It testifies to the fact that it is an activity, praxis, involving the spectator in the actualisation of different temporalities.

Godard's fleeting point of view and a-chronological movements through time and space bring together things and times "that have not been brought together before, and do not seem liable to be brought together at all." He exhibits the images of our everyday while establishing a relation to these images and making the co-existence of their different temporalities, their contemporaneity in the historical present, felt-it is an aesthetics of contemporaneity in opposition to "the systematic organization of the unified time of the moment. This global, abstract tyranny." 
Jean-Luc Godard, Histoire(s) du cinéma [1998], DVD Gaumont, 2008, Chapter 4B. 16.

Bernard Stiegler, "Dans la vacance, on cherche à retrouver la consistance dans son existence," philosophie magazine no. 21 (2008), accessed May, 25, 2015, http://www.philomag.com/les-idees/ bernard-stiegler-dans-la-vacance-on-cherche-a-retrouver-la-consistance-dans-son-existence. Means without End: Notes on Politics, trans. Vincenzo Binetti and Cesare Casarino (Minneapolis, London: University of Minnesota Press, 2000), 76. MenschenDinge/The Human Aspect of Objects, Weimar: Stiftung Gedenkstätten (Buchenwald und Mittelbau-Dora, 2006), 10.

Hito Steyerl, “Too Much World: Is the Internet Dead?," in e-flux journal no.49 (November 2013), 07/10, accessed May 25, 2015,http://www.e-flux.com/journal/too-much-world-is-the-internetdead/

Peter Osborne, Anywhere or not at all. Philosophy of Contemporary Art (London: Verso, 2013), 17.

Terry Smith, "Contemporary Art and Contemporaneity," in Critical Inquiry 32 (Summer 2006): 703.

Cf. Michael Witt, introduction to Histoire(s) du cinéma (1988-1998) by Jean-Luc Godard, in Screen 40:3 (Autumn 1999): 304-305.

the Iconology of the Interstice," Third Text, 27:6 (2013): 778.

11 Cf. Monica Dall'asta, "The (Im)possible History," in For Ever Godard, eds. Michael Temple et al. (London: Black Dog Publishing, 2004), 352.

12 Cf. Kriss Ravetto-Biagioli, "Noli me tangere. Jean-Luc Godard's Histoire(s) du cinéma," in $A$ Companion to Jean-Luc Godard, Malden, eds. Tom Conley and T. Jefferson Kline (MA \& Oxford: Wiley Blackwell, 2014), 461.

Jacques Rancière, The Future of the Image, trans. Gregory Elliott (London \& New York: Verso, 2007), 62-63.

My description of this fragment draws heavily upon Ravetto-Biagioli, 472, and Williams, 14.

Cf. Trond Lundemo, "Godard as Historiographer," in A Companion to Jean-Luc Godard, eds. Tom Conley and T. Jefferson Kline, 496.

I here draw upon the description of photofilmic time economies in the program for the conference Photofilmic Images in Contemporary Art and Visual Culture, accessed May, 25, 2015,http:// photofilmic.com/photofilmic-images-in-contemporary-art-and-visual-culture-conference/ Cf. Monica Dall'asta, "The (Im)possible History,"

Walter Benjamin, "Theses on the Philosophy of History," in Illuminations, trans. Harry Zohn (New York: Schocken Books, 1969), 255.

Walter Benjamin, The Arcades Project, trans. Howard Eiland \& Kevin McLaughlin (Cambridge, MA \& London: The Belknap Press of Harvard University Press, 1999), 462f. (my italics)

Georges Didi-Huberman, "Opening the Camps, Closing the Eyes: Image, History, Readability," in Concentrationary Cinema. Aesthetics as Political Resistance in Alain Resnais's Night and Fog (1955), eds. Griselda Pollock and Max Silverman (New York \& Oxford: Berghahn Books, 2011), 87.

Filmcomment, interview: Jean-Luc Godard, accessed May, 25, 2015, http://www.filmcomment. com/article/jean-luc-godard-interview-nouvelle-vague-histoires-du-cinema-helas-pour-moi. Jean-Luc Godard \& Youssef Ishaghpour, Archéologie du cinéma et mémoire du siècle (Tours: Farrago, 2000), 27. 
Agamben, Giorgio. "Marginal Notes on Commentaries on the Society of the Spectacle." In Means without End: Notes on Politics, 73-90. Translated by Vincenzo Binetti and Cesare Casarino. Minneapolis, London: University of Minnesota Press, 2000.

Benjamin, Walter. The Arcades Project. Translated by Howard Eiland \& Kevin McLaughlin. Cambridge, MA \& London: The Belknap Press of Harvard University Press, 1999.

Benjamin, Walter. "Theses on the Philosophy of History.” In Illuminations, 253-264. Translated by Harry Zohn. New York: Schocken Books, 1969.

Dall'asta, Monica. “The (Im)possible History.” In For Ever Godard, edited by Michael Temple et al., 350-363. London: Black Dog Publishing, 2004.

Didi-Huberman, Georges. "Opening the Camps, Closing the Eyes: Image, History, Readability." In Concentrationary Cinema. Aesthetics as Political Resistance in Alain Resnais's Night and Fog (1955), edited by Griselda Pollock and Max Silverman, 83-125. Translated by Katie Tidmarsh. New York \& Oxford: Berghahn Books, 2011.

Godard, Jean-Luc. Histoire(s) du cinéma [1998], DVD. Paris: Gaumont, 2008.

Godard, Jean-Luc.Interview.In Filmcomment. Accessed May, 25, 2015, http://www. filmcomment.com/article/jean-luc-godard-interview-nouvelle-vague-histoires-du-cinemahelas-pour-moi.

Godard, Jean-Luc, and Youssef Ishaghpour.Archéologie du cinéma et mémoire du siècle. Tours: Farrago, 2000.

Latsis, Dimitrios S. "Genealogy of the Image in Histoire(s) du Cinéma: Godard, Warburg and the Iconology of the Interstice." Third Text 27:6 (2013): 774-785.

Lundemo, Trond. "Godard as Historiographer." In A Companion to Jean-Luc Godard, edited by Tom Conley and T. Jefferson Kline, 488-503. Malden, MA \& Oxford: Wiley Blackwell, 2014.

Osborne, Peter. Anywhere or not at all. Philosophy of Contemporary Art. London: Verso, 2013.

Rancière, Jacques. "Die Arbeit des Bildes/The Work of the Image," in Esther ShalevGerz:MenschenDinge/The Human Aspect of Objects, 8-25.Weimar: StiftungGedenkstätten Buchenwald und Mittelbau-Dora, 2006.

Rancière, Jacques. The Future of the Image. Translated by Gregory Elliott. London \& New York: Verso, 2007.

Ravetto-Biagioli, Kriss. “Noli me tangere. Jean-Luc Godard's Histoire(s) du cinéma.” In A Companion to Jean-Luc Godard, edited by Tom Conley and T. Jefferson Kline, 456-487. Malden, MA \& Oxford: Wiley Blackwell, 2014.

Smith, Terry. "Contemporary Art and Contemporaneity." Critical Inquiry 32 (Summer 2006): 681-707.

Smith, Terry. Thinking Contemporary Curating. New York: Independent Curators International, 2012.

Steyerl, Hito. “Too Much World: Is the Internet Dead?.” e-flux journal \#49 (November 2013): 1-10. Accessed May 25, 2015, http://www.e-flux.com/journal/too-much-world-is-the-internetdead/

Stiegler, Bernard. "Dans la vacance, on cherche à retrouver la consistancedans son existence". philosophie magazine 21 (2008), accessed May, 25, 2015, http://www.philomag.com/ les-idees/bernard-stiegler-dans-la-vacance-on-cherche-a-retrouver-la-consistance-dans-sonexistence

Williams, James S. "Histoire(s) du cinéma”.Film Quarterly 61:3 (Spring 2008): 10-16.

Witt, Michael. "Introduction. Jean-Luc Godard: Histoire(s) du cinéma (1988-1998).” Screen 40:3 (Autumn 1999): 304-305. 


\section{"NEPRIJATELJ NAŠEG DOBA": GODAROVA ESTETIKA SAVREMENOSTI NASUPROT SINHRONIZACIJI \\ Jakob Lund}

Pred kraj svog filmskog eseja Histoire (s) du cinema Žan-Luk Godard sebe naziva 'neprijateljem našeg doba', 'totalitarizma sadašnjosti primenjenog mehanički svakim danom sve više represivno na planetarnom nivou.' Članak gleda Histoire(s) du cinema (1988-1998) kao 'oblik razmišljanja' koji pokušava da se odupre sinhronizaciji, standardizacionom vremenu globalnog kapitala, sveprisutnoj uniformnosti svetske super-sadašnjosti, koje donosi današnja televizijska i digitalna komunikacija, koja preti da trivijalizuje različite procese memorije i istorije i umetnosti i kulture uopšte. Prema filozofu Bernardu Štigleru, završna faza kapitalizma je kontrola i sinhronizacija onoga što je bivši direktor TF1 Patrick Le Lai nazivao 'dostupno vreme mozga'. U radu se ističe da se rad Godarda protivi ovoj kontroli i sinhronizaciji naših umova kroz estetiku savremenosti. Argument je zasnovan na razvoju teorijskog okvira koji kombinuje najnovije teorije savremenosti sa teorijama sliko-politike. Fokusirajući se na povezanost pojedinca, društvene i medijske sredine, rad će se baviti Godardovo, je sliko-političkim stvaranjem vremenske savremenosti kroz montažu snimaka starih filmova i filmskih žurnala, fotografija, fotografija bez pokreta, snimaka slika, novih snimka, reklama, muzika, zvuka i snimaka govora, tekstualnih citata, priča i komentara.

KLJUČNE REČI: SAVREMENOST, SLIKO-POLITIKA, TELEVIZIJA, VREMENSKO ISKUSTVO, GODARD

\section{ARHITEKTONSKI HIBRIDI NA KALEIDOSKOPSKOJ FOTOGRAFIJI \\ Maria Romakina}

Ovaj rad se fokusira na temu koja je na neki način raskrsnica između dve oblasti: fotografija i arhitektonska morfogeneza. Posebno interesovanje članka je savremena fotografska tendencija da se istraži kaleidoskopska tehnika i estetika u odnosu na arhitektonske objekte i urbane sredine. Paradoksalno ovo su fotografi koji istražuju ovu posebnu vrstu morfogeneze arhitektonske forme. Međutim, neki od njih su originalno arhitekte. Obraćajući pažnju na istorijske i evolutivne aspekte kaleidoskopske slike u 19. veku i kaleidoskopske fotografske prakse američkog umetnika Alvina Langdona Koburna i njegovih sledbenika u 20. i 21. veku, rad ima za cilj da analizira potencijal fotografije u razvoju arhitektonske forme primerima projekta Matije Mogneti, Borbale Suto-Nagi, Korija Stevensa, Stefana Laniraia, Panosa Papanagiotua, Andreja Čegina, Muhameda Domirija i onih fotografa koji su inspirisani radom kamere iz filma 'Inception' - Ben Tomas, Kazuhiko Kavahara, Simon Gardiner, Nikolas Kenedi Siton.

KLJUČNE REČI: KALEIDOSKOP, ARHITEKTURA, APSTRAKCIJA, HIBRIDNA STRUKTURA, FOTOGRAFIJA, VORTOGRAF ALVIN LANGDON COBURN, MAURITS CORNELIS ESCHER, FILM "INCEPTION"

SINEMATSKI ASPEKT ARHITEKTURE:

\section{ULOGA VREMENA U DISKUSIJI O ALTERNATIVNIM ARHITEKTONSKIM STRATEGIJAMA}

\section{Katarina Anđelković}

U potrazi za načinima za prevazilaženje negativnih konotacija primene karakteristično tradicionalnih metoda prakse u trenutnom regulisanju prostorno-vizuelnih parametara urbanog okruženja, krećemo se ka razmatranju alternativnoj 'arhitekturi odnosa'. Rad razjašnjava kako film može ponuditi alternativno mesto u arhitekturi, gde su urbani prostori smišljeni i dizajnirani u bližem odnosu sa potencijalima filma da manipulišu realnost, promene način percepcije, daju viziju i rekonstruišu nesvesne impulse metropole. Eksperimentalni dizajni pokazuju kako odzvanjajući zapisi prostora, vremena i kretanja kroz prostor može simulisati impuls mapiranja koji inspiriše alternativni pristup dizajniranju prostora. Moj pristup se oslanja na različite proizvodne platforme znanja da detektuje vremensko srodstvo između filmskog i stvarnog prostora. Oni su ovde navedeni u kontekstu postmodernih diskusija da otkriju novu interakcijsku tačku između filma i arhitekture, u cilju podrške režima zasnovanih na vremenu prijema arhitektonskih i urbanističkih ideja. 